\title{
THE EFFICIENCY OF ACTIVE LABOUR MARKET POLICIES IN THE EUROPEAN UNION: DOES IT MAKE SENSE INCREASING THE BILL?*
}

\author{
Juan González ALEGRE \\ (Received: 25 January 2016; 9 August 2016; \\ accepted: 19 September 2016)
}

This paper evaluates the efficiency of Active Labour Market Policies (ALMPs) in the European Union (EU). The paper first reviews the main trends governing the evolution of the European Social Fund (ESF) since its creation. The ESF promotes public expenditure in ALMPs in order to foster social cohesion across the EU. In order to test to what extent this strategy can be backed up by facts, we estimate the impact of public expenditure on ALMPs on the employment rate using panel data from 28 European countries (1985-2011), taking into account the endogeneity of the explanatory variables and the dynamic behaviour of their relationship. Results support the hypothesis that expenditure in ALMPs is more beneficial for employment than aggregate public expenditure. In addition, we show that periphery countries observe a larger efficiency of their ALMPs. These results support the recent policy strategy undertaken by the European Commission to raise the budget devoted to ESF in Member States experiencing higher unemployment rates.

Keywords: Active Labour Market Policies, European Social Fund, panel data, intergovernmental relations

JEL classification indices: C23, H53, H77, J48

* This work was supported by the "Cátedra Pasqual Maragall de Economia y Territorio" under the "Ayudas a la Investigación 2012" grants program, the "Generalitat de Catalunya AGAUR" research grants program (Grant no. 2014-SGR-1326) and the Spanish Ministry of Economics (Grant no. ECO2014-52999-R), whose patronage is gratefully acknowledged.

Juan González Alegre, Associate Professor at the Department of Economics, University of Málaga, and Department of Applied Economics of Autonomous University of Barcelona, Spain.

E-mail: jgonzalezal@uma.es 


\section{INTRODUCTION}

As the second decade of the $21^{\text {st }}$ century started in the EU, the problems in its labour market became apparent, ${ }^{1}$ with the unemployment rate exceeding $10 \%$, far above other developed regions of the world. Asymmetries in unemployment levels did not only persist, but became wider as the economic crisis hit the continent. These asymmetries appeared mainly, but not only, across the different Member States (MS). There was a gap of 20 percentage points between the two MSs with the highest and lowest unemployment rates. But asymmetries arose also across other dimensions of the labour market, which indicate that despite the fact that more than 26 million people were unemployed in the EU, there were significant skill mismatches on Europe's labour market and, paradoxically, a high level of unfilled vacancies continue to persist.

Youth unemployment rate was more than twice as high as the adult one. The EU was determined to undertake policy actions in order to rectify this trend. On February 8, 2013, the European Council proposed to carry out the Youth Employment Initiative that was intended to support young unemployed citizens in regions with a particularly high level of youth unemployment rate (above $25 \%$ ). For this purpose, the European Council allocated a budget of $€ 6$ billion for the period 2014-2020, one-half of which will be channelled through the European Social Fund (ESF).

The ESF is one of the tools of Structural Actions, and is devoted to promote public expenditures for Active Labour Market Policies (ALMPs). The ESF was set up under the Treaty of Rome, and its importance as a fiscal and a policy tool has been increasing, in parallel to the other Structural Actions. The growing importance of the ESF, in particular, and the ALMPs that the ESF is intended to boost, make imperative the necessity of identifying to what extent they are effective in lowering unemployment rates.

For this purpose, we first analyse the main trends governing the evolution of the ESF. Then, we construct and estimate an econometric model that evaluates the impact of ALMPs public expenditure on the employment rate, using panel data from the MSs for the period 1985-2011. In order to focus our attention on those MSs with more problematic labour markets, the analysis distinguishes between countries highly subsidised by the ESF and those countries that receive relatively less funds. We conclude that ALMPs are more efficient precisely in the countries with more problematic labour markets. This result supports the recent strategy of the EU of reinforcing the ESF as a tool to enhance social cohesion across European countries.

1 Information and data mentioned in the Introduction have been extracted from Eurostat and European Commission (2013). 


\section{THE EUROPEAN SOCIAL FUND AS A FISCAL TOOL TO ENLARGE PUBLIC SPENDING IN ALMPs}

The ESF's original task was to promote employment and the geographical and occupational mobility of workers within the Community. ${ }^{2}$ The ESF was founded upon the principles of the Fund for the Retraining and Resettlement of Workers, its predecessor in the European Coal and Steel Community. During its first two decades, due to the low levels of unemployment in the European Economic Community, the ESF was devoted to facilitating the migration of workers and to retrain people who had suffered accidents at work (European Commission 2007). The importance of the ESF on the European economy was minor during this period, representing around $1 \%$ of the total budget and less than $0.01 \%$ of GDP. ${ }^{3}$

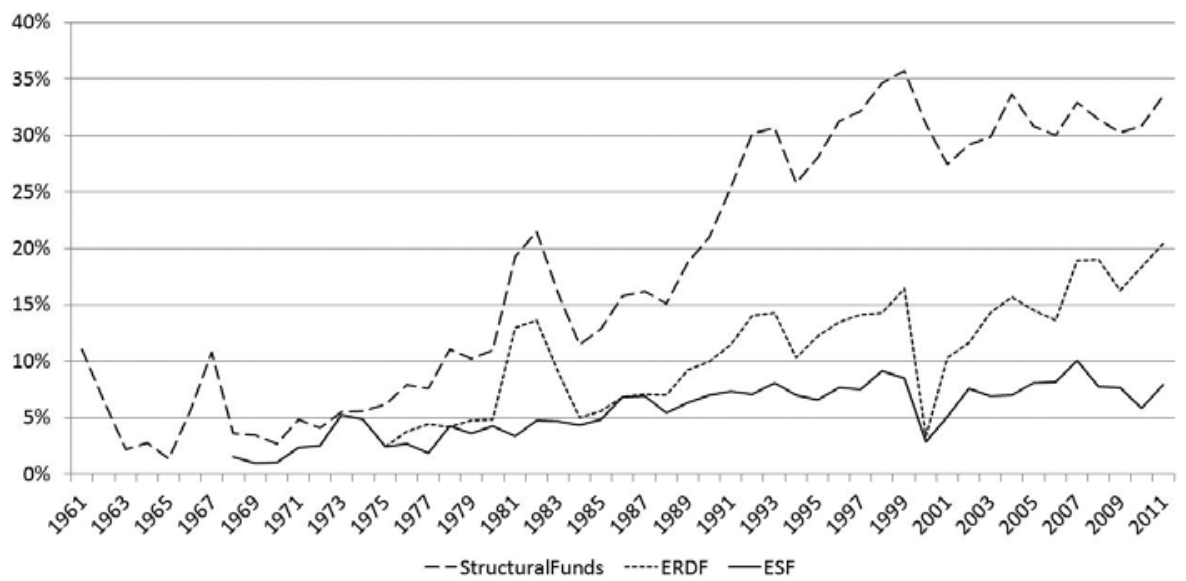

Figure 1. Evolution of the European Structural Funds (as a share of the total budget of the European Communities/ European Union)

Sources: Own compilation from the EU budget (several years) Financial Report, Eurostat, and OECD.

2 The great majority of the Funds are devoted to finance Active Labour Market Policies, as analysed in European Commission (2010). The ESF regulation describes the particular conditions of the projects financed for every programming period (The Council Regulation (EEC) No. 2052 / 88 of June 24, 1988, The Regulation (EC) No. 1784/1999 of the European Parliament and of the Council of July 12, 1999, on the European Social Fund, and Regulation (EC) No. 1081/2006 of the European Parliament and of the Council of July 5, 2006, on the European Social Fund), and they refer mostly to ALMPs-related projects.

3 The Structural Funds represented altogether around 5\% of the total European Communities budget during the 1960s (European Communities 2009), which in turn represented around $0.5 \%$ of the GDP of the 6 MSs. 


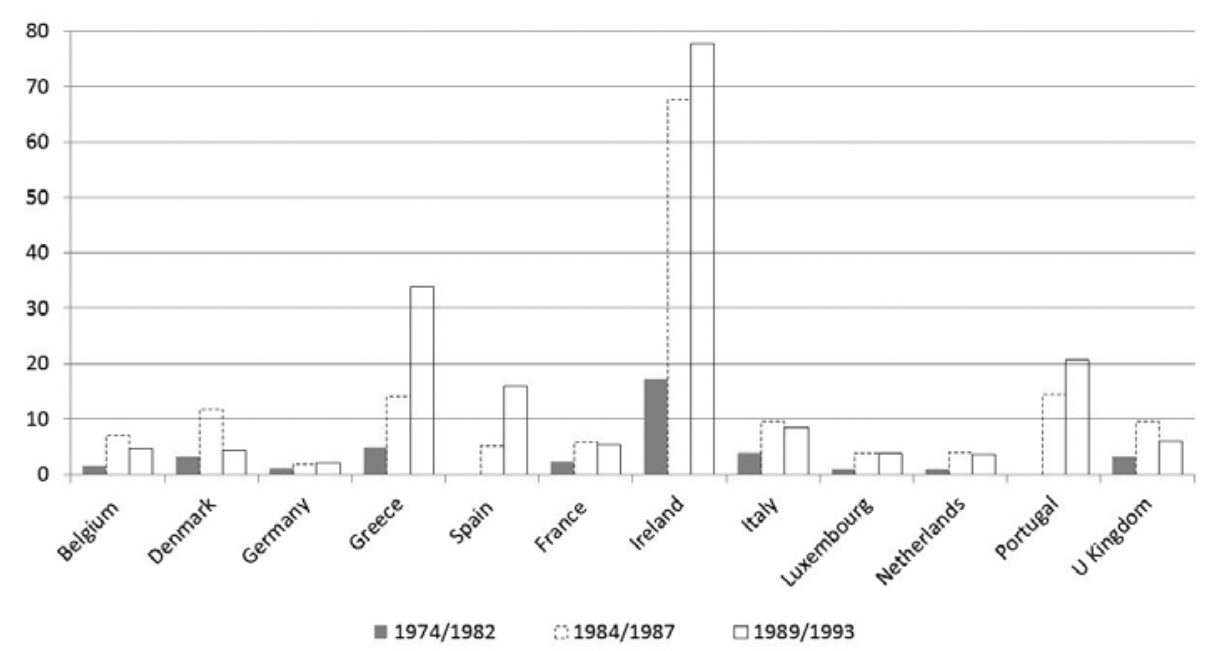

Figure 2. Allocation of the ESF: Programming period 1974-1982, 1984-1987, 1989-1993 Average annual allocation per inhabitant (in per capita ECU)

Sources: Commission of the European Communities (1983), Report and proposals on ways of increasing the effectiveness of the Community's structural Funds, Brussels, OPOCE COM (83) 501 (Commitments); Commission of the European Communities (1989), Guide to the reform of the Community's structural Funds, OPOCE: Brussels ISBN: 92-826-0029-7 (Commitments) and Commission of the European Communities (1990), Annual report on the implementation of the reform of the Structural Funds 1989, Brussels EC (COM(90) 516 final).

The European Regional Development Fund (ERDF) created in 1975 devoted to promote infrastructure in regions lagging behind. The ESF and ERDF are referred to as "Structural Funds". Initially, MSs implemented projects that were re-funded afterwards, but as access to Fund started to cover wider policy areas, a system of prior approval was introduced (Bache et al. 2011). Although Italy, the United Kingdom, and France were the main beneficiaries of the allocation of the ESF in absolute terms during these years, the allocation of funds per inhabitant were clearly focused towards Ireland whose advantage over the other MSs was remarkable.

The size of the Fund was consequently enlarged, as Portugal and Greece joined Ireland ${ }^{4}$ as main recipient states. The Structural Funds were substantially reformed in 1988, with the purpose of moving from individual projects to multiannual partnerships between the MSs and the Commission. This reform also included an increase in the financial weight of the ESF. ${ }^{5}$ The new approach was

4 In terms of GDP, Ireland $(0.86 \%)$ and Portugal $(0.50 \%)$ were the greatest beneficiaries, while Luxembourg $(0.02 \%)$ and Netherlands $(0.03 \%)$ were the least favoured.

$5 \quad$ For this programming period, in terms of GDP, Ireland $(0.69 \%)$ and Greece $(0.43 \%)$ were at the top of the list, while Luxembourg $(0.01 \%)$ and Denmark $(0.02 \%)$ were at the bottom. 


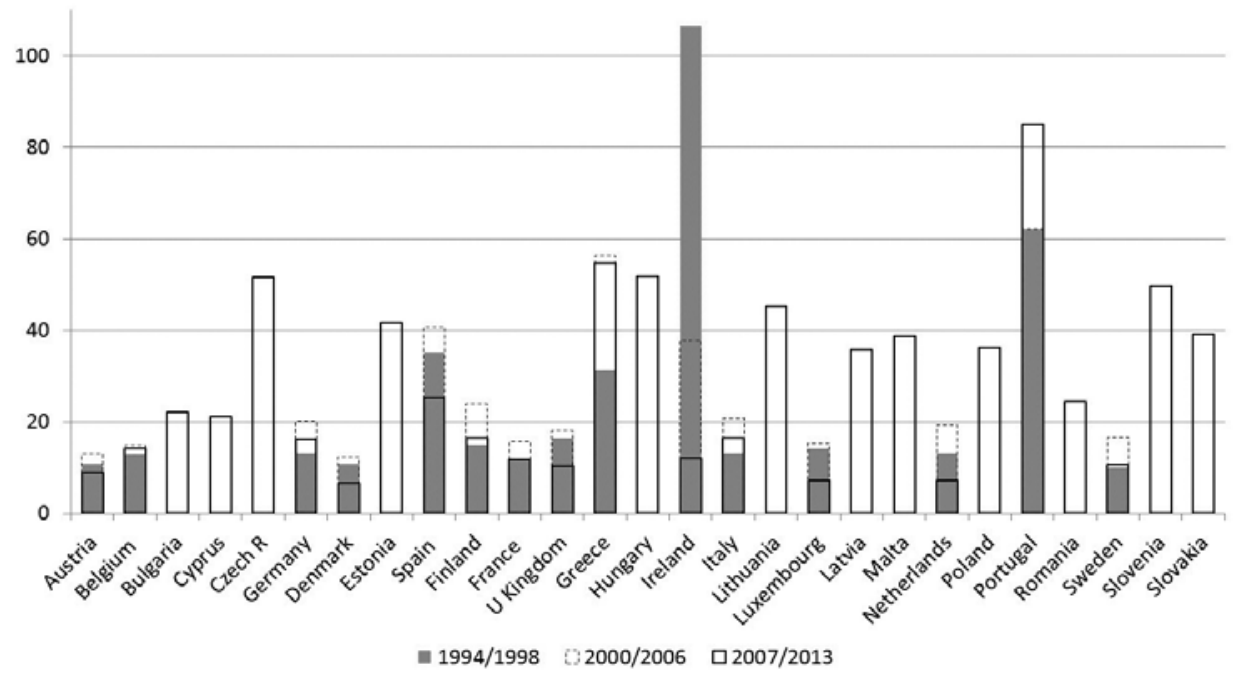

Figure 3. Allocation of the ESF: Programming periods 1994-1998, 2000-2006, and 2007-2013 Average annual allocation per inhabitant (in per capita Euro)

Sources: European Commission (1999), The Structural Funds in 1998 10th Annual report, OPOCE: Brussels COM(99) 467 final (Commitments); Commission of the European Communities (2004), 15th Annual report on the implementation of the Structural Funds 2003, Brussels COM(2004) 721 final (Initial allocations) and ESF Database portal at http://ec.europa.eu/esf/main.jsp?catId=440\&langId=en\#opt1 (ESF Initial financial allocations as at 31.12.2007).

built on four basic principles: Concentration, in determined regions or policy objectives; partnership, with national, regional, or local authorities; programming, setting the priorities and allocation for each period (5-7 years); and additionality, as the funds were not intended to replace, but to increase national funds. As long as the ESF is mainly involved with ALMPs, the principle of additionality applied to the ESF implies that the transfers are intended to encourage larger public expenditure in subsidies policies.

In 1992, the Single Market reached its completion and the way towards the single currency was clearer. The review of the Structural Funds in 1993 was focused towards strengthening economic and social cohesion, and its budgets were almost doubled for the period 1994-1999. ${ }^{6}$ The ESF was targeted to increase competitiveness and to prevent unemployment through education and training activities focused on workers with higher risk of exclusion such as young job-seekers or

6 The average allocation, as a share of GDP, did not change substantially for the countries with the higher subsidies, namely Portugal $(0.64 \%)$ and Ireland $(0.62 \%)$. However, this is not the case for those countries with lower subsidies, namely Luxembourg $(0.03 \%)$ and Denmark $(0.03 \%)$. 


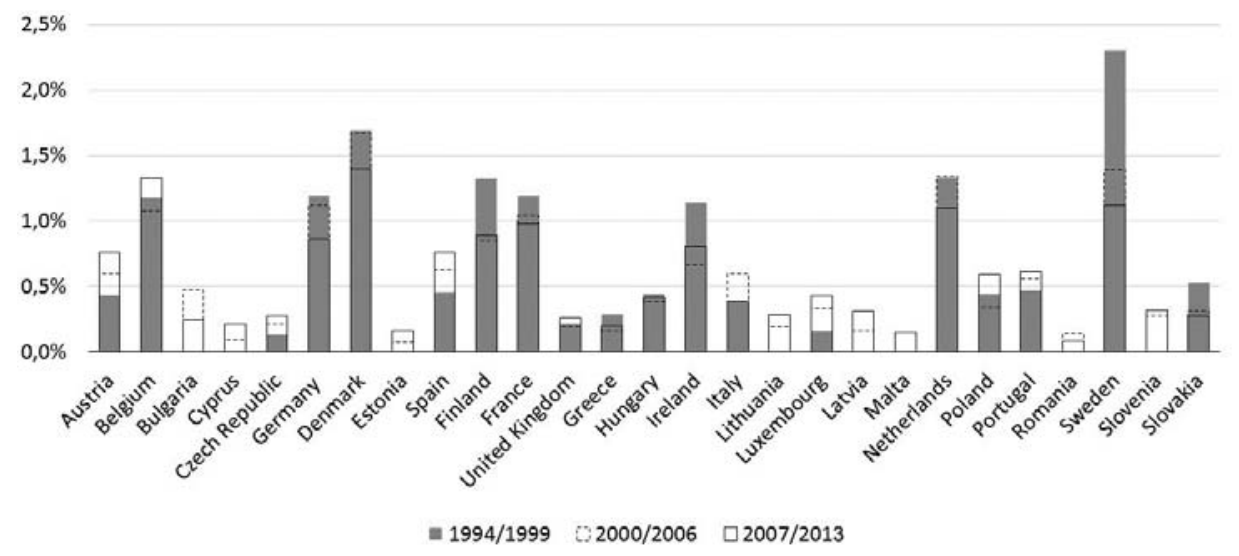

Figure 4. Public expenditure in ALMPs: 1994-1999, 2000-2006 and 2007-2013 (\% of GDP)

Sources: Eurostat and OECD Employment database.

long-term unemployed within the framework of the Commission's White paper on Growth, Competitiveness and Employment.

The ESF was geared towards supporting the European Employment Strategy as a part of the Lisbon Strategy at the beginning of the 21st century. ${ }^{7}$ The ESF would then target the four pillars of the European Employment Strategy: enhancing the skills and flexibility of the workforce; development of active labour market measures in order to prevent youth long-term unemployment; development of small- and medium-sized enterprises by enhancing entrepreneurship potential; and promoting equal opportunity and preventing social exclusion within the labour market.

The programming period 2007-2013 involved the substantial reorganisation of the Cohesion Policy. ${ }^{8}$ The rules were simplified and the Funds were targeted specifically towards the promotion of competitiveness and employment creation. The link of the ESF with the European Employment Strategy was strengthened and the Fund's priorities focused on convergence and employment objectives (European Commission 2007b).

7 For the programming period 2000-2006, the countries with a larger allocation of ESF relative to the size of their economy were Portugal $(0.45 \%)$ and Greece $(0.36 \%)$. The lowest allocations were for Luxembourg $(0.03 \%)$ and Denmark $(0.03 \%)$.

8 As a share of GDP, during the programming period 2007-2013, the countries with larger transfers are Hungary $(0.53 \%)$ and Bulgaria $(0.46 \%)$, and those with lower are Luxembourg $(0.01 \%)$ and Denmark $(0.01 \%)$. 
The key question, at this point, is to assess whether the ESF has been effective in raising ALMPs expenditures in the subsidised countries. This issue is beyond the scope of this paper and is, in fact, a very relevant - but complicated - point to address. We may, however, give a brief overview of the comparison and evolution of the level of public expenditures on ALMPs, making use of the dataset used to estimate the models presented later.

Figure 4 was designed to make an intuitive visual comparison with Figure 3. We could identify, broadly, three main groups of countries: first we have a group of core European countries in which, with the remarkable exception of the UK, public expenditure on ALMPs is larger; next, we see the older member states of the periphery that are devoting around $0.5 \%$ of their GDP to publicly-promoted ALMPs, with Greece lagging behind; and, finally, the New Member States (NMS) with a far smaller effort, but some of them responding positively to their use of the Structural Funds. Although it is difficult to know to what extent these figures are the result of the implementation of the ESF and its inertia, Figure 4 nonetheless illustrates the size of the gap in the level of performance across countries.

\section{MODELLING THE IMPACT OF ACTIVE LABOUR MARKET POLICIES}

This paper makes use of a panel data model in order to estimate the impact of ALMPs on employment in two sub-groups of EU countries. This section includes a brief review of previous studies using a similar empirical approach with a double purpose: firstly, it shows that the increasing interest of the EC (described in the previous section) in fostering public expenditures on ALMPs responds to the growing evidence that ALMPs improve labour market performance; and secondly, previous results will motivate the use of variables and the econometric modelling described in the next sections.

Jackman et al. (1990) found for a panel of 14 OECD economies during the period 1970-1988 that ALMPs have a significant impact on unemployment (other studies are Layard et al. 1991; Zetterberg 1995). OECD (1993) revealed that previous results were sensitive to the measure of ALMPs, so that when this variable is expressed as a ratio over the number of unemployed, it could be highly correlated with the dependent variable (unemployment rate), leading to spurious correlation. Forslund - Krueger (1997) also made a critical revision of previous estimations in which they identified a source of simultaneity bias between unemployment and expenditure on ALMPs and a possible change in the relationship between both variables during the 1990s. Elmeskov et al. (1998) addressed the simultaneity bias by averaging their indicator of expenditure on ALMPs over the 
whole period, while Nickell - Layard (1999) used one-period lagged values of expenditure on ALMPs. In both cases, the impact of ALMPs on unemployment seems less relevant than in previous studies.

Blanchard - Wolfers (2000) interacted labour market institutional variables with adverse shocks in the form of time dummies for five-year averaged variables, and concluded that the heterogeneity observed in unemployment among OECD countries depends on the interaction of common shocks with idiosyncratic institutional variables (the interaction of institutional variables is widely analysed in Basasini - Duval 2009), among which the size of ALMPs is included. The branch of the literature focusing on the institutional determinants of unemployment has been quite prolific during the first decade of the 21st century (see, for example, Baccaro - Rei 2005; Nickel et al. 2005; Sachs 2012) and their results have motivated the inclusion of institutional variables among the set of controls in studies analysing the impact of ALMPs.

Other studies (Hujer - Caliendo 2000; Hujer - Zeiss 2003) related the number of hirings to the number of vacancies, the unemployed, and other control variables, among which ALMPs are included. The use of an indicator of the outflows from unemployment to employment as the dependent variable has the advantage that this variable internalises the displacement effects (crowding-out) of ALMPs, that is, it accounts also for the substitution of workers indicated by the policy.

Estevao (2007) estimated the determinants of employment rate in the private sector and included expenditure on ALMPs as a share of GDP, arguing that normalising this variable by unemployment might bias the results because aggregate output shocks could affect both variables simultaneously, provoking spurious correlation. He concluded, for a panel of 16 OECD countries (1985-2000) that ALMP were very effective in increasing business employment rates in the 1990s.

Boone - van Ours (2009) distinguished several types of ALMPs in a panel data of 20 OECD countries (1985-1999) and concluded that the impact on unemployment (and on the employment/population rate) varies significantly among categories of ALMPs. More recent studies such as Vis (2012) and Váradi (2013) suggest the introduction of a correction to the - disaggregated - subcategories of ALMPs expenditure by reporting figures in relative terms to covered population.

\section{DATA AND VARIABLES}

We use country-level yearly data in order to estimate the impact of ALMPs on the employment rate. For this purpose, we use data from an unbalanced panel of 28 


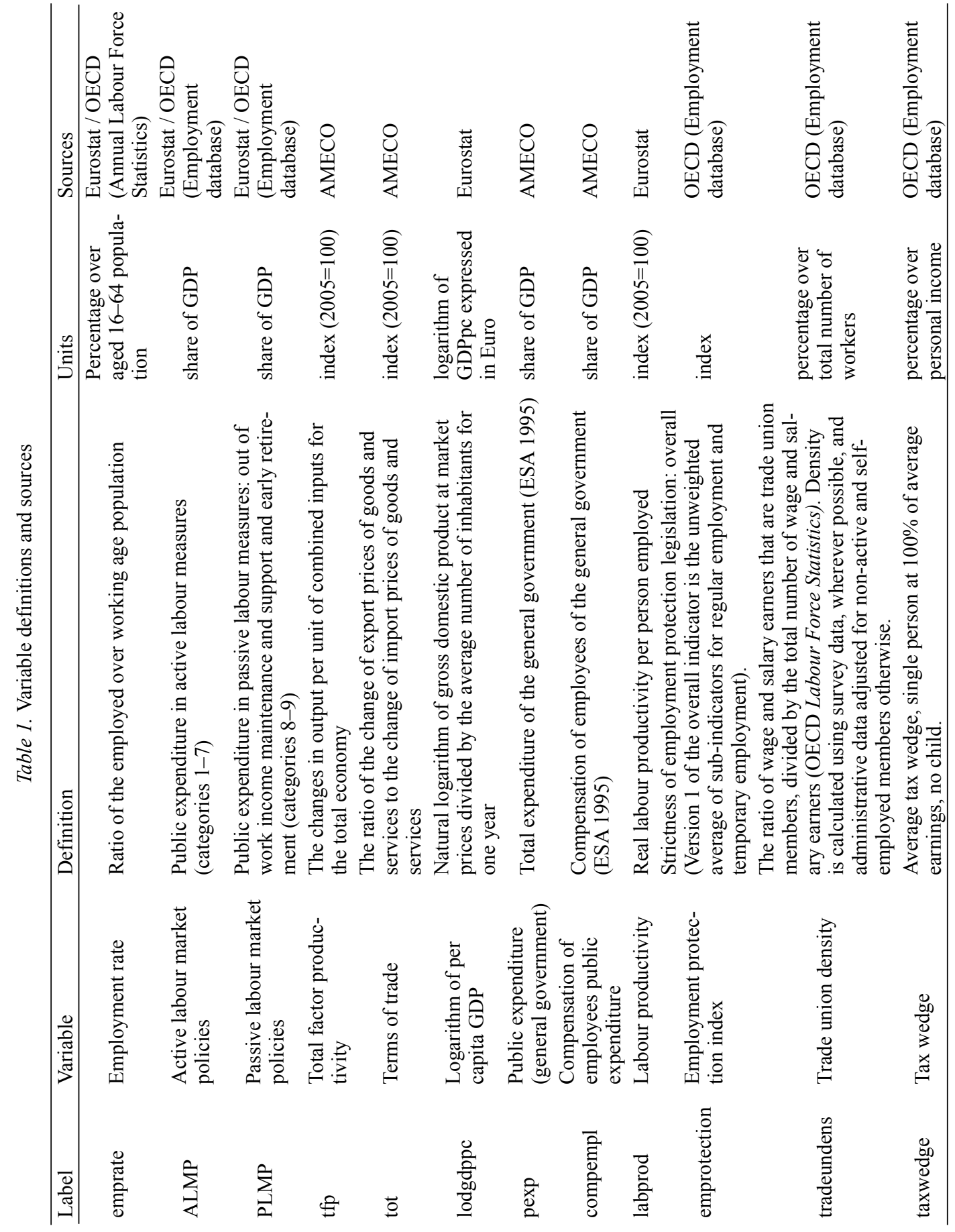


Table 2. Summary statistics

\begin{tabular}{|c|c|c|c|c|c|c|c|c|c|c|}
\hline \multirow[b]{2}{*}{ Variable } & \multicolumn{5}{|c|}{ Periphery countries } & \multicolumn{5}{|c|}{ Core countries } \\
\hline & Obs. & Mean & $\begin{array}{l}\text { Std. } \\
\text { Dev. }\end{array}$ & Min. & Max. & Obs. & Mean & $\begin{array}{l}\text { Std. } \\
\text { Dev. }\end{array}$ & Min. & Max. \\
\hline emprate & 379 & 60.85 & 6.4 & 45.4 & 81.3 & 267 & 68.31 & 6.6 & 52.5 & 81.5 \\
\hline ALMP & 294 & 0.37 & 0.28 & 0.02 & 1.47 & 252 & 0.79 & 0.49 & 0.04 & 2.52 \\
\hline PLMP & 296 & 0.97 & 0.88 & 0.08 & 5.42 & 257 & 1.61 & 1.01 & 0.16 & 5.45 \\
\hline tfp & 381 & 92.58 & 10.6 & 57.2 & 115.9 & 280 & 92.03 & 8.3 & 72.0 & 104.6 \\
\hline tot & 414 & 98.59 & 7.0 & 64.0 & 128.5 & 280 & 97.99 & 9.8 & 60.1 & 123.9 \\
\hline lodgdppc & 411 & 9.03 & 0.9 & 6.0 & 10.7 & 273 & 10.17 & 0.4 & 9.2 & 11.3 \\
\hline pexp & 380 & 43.46 & 6.6 & 24.3 & 78.1 & 256 & 50.02 & 6.0 & 36.3 & 71.7 \\
\hline compempl & 394 & 10.96 & 2.2 & 2.9 & 17.7 & 261 & 12.06 & 2.9 & 7.1 & 19.4 \\
\hline labprod & 387 & 90.22 & 17.5 & 42.2 & 132.2 & 271 & 88.92 & 11.8 & 60.9 & 106.4 \\
\hline emprotection & 290 & 2.31 & 0.9 & 0.9 & 4.2 & 280 & 2.37 & 0.8 & 0.6 & 3.5 \\
\hline tradeundens & 297 & 32.87 & 17.4 & 7.1 & 80.7 & 280 & 43.26 & 21.4 & 7.6 & 83.9 \\
\hline taxwedge & 272 & 40.66 & 6.5 & 22.2 & 54.5 & 280 & 43.93 & 7.1 & 29.5 & 56.9 \\
\hline
\end{tabular}

European countries ${ }^{9}$ for the time period 1985-2012. The sample was divided into two subsamples with the purpose of distinguishing between two different groups of countries: on the one hand, we consider the core countries, which are the central and northern older MSs, reporting a better performance in their labour markets (and, therefore, receiving lower ESF support); on the other hand, we include the NMSs and the periphery, which are countries that experienced high unemployment rates or other labour market-related problems (they, accordingly, received larger ESF transfers relative to their size).

Variable description and sources are described in Tables 1 and 2. The dependent variable is the employment rate in the population aged 16-64, and it has been retrieved from the Eurostat database, although some observations have been extracted from the "Population and Labour Force" dataset which is part of the "Annual Labour Force Statistics" (ALFS) compiled by the OECD (the compatibility between both sources has been examined on the basis of simultaneous observations).

The first decision to take when building a model that tries to estimate the impact of ALMP is the selection of the dependent variable to be included in the model. Originally, most studies ${ }^{10}$ used the unemployment rate. However, inspired

9 The database also includes Norway, which is not a member state of the EU, but it is a member of the EEA. The EEA is not involved in the EU Regional policy directly, but it does participate in EU programmes related to Employment and Social protection (among other objectives) through the so-called EEA Grants and Norway Grants. Croatia was not included in, because she was not a MS in 2012.

10 See Chapple (1999) for a survey of pioneering studies. 
by the survey of the literature, ${ }^{11}$ we used the employment rate over the total working age population as the dependent variable of our model.

The explanatory variable on which we focus our interest is "Active Labour Market Policies". The level of public expenditure ${ }^{12}$ on ALMPs is expressed as a share of GDP. "Passive Labour Market policies" (PLMPs) is also included among the set of explanatory variables, as PLMPs have been clearly identified as a strong (positive) determinant of unemployment by previous studies. The main data source is Eurostat, although some observations have been retrieved from the OECD Employment database. Fiscal data are collected for the general public sector, which includes all the levels of the public administration, as the distribution of fiscal competencies is extremely heterogeneous across EU Member States.

Regarding the use of other control variables, the set of variables used in previous panel data studies has been extremely heterogeneous as a result of the different hypotheses taken into account. We include a set of macroeconomic indicators and a set of institutional indicators, inspired by the review of the relevant literature and preliminary estimations.

Our macroeconomic indicators used as explanatory variables are total factor productivity, the terms of trade, per capita GDP (expressed in logs), public expenditure (as a share of GDP), compensation of employees in the general government (as a share of GDP), and labour productivity. These have been retrieved from Eurostat and Ameco databases.

Finally, and inspired by the importance that some studies set on variables capturing institutional settings of the labour market (see, for example, the findings described in Flaig - Rottmann 2013), we also considered some institutional variables taken from the OECD Employment database: the employment protection

11 Scarpetta (1996) finds that ALMPs may increase the labour force participation rate, which suggests that the use of a ratio of unemployed people over working age population (or, alternatively, its inverse, the employment rate) would capture more accurately the desired effect (Nickell-Layard 1999). Hujer et al. (2004) use the rate of job seekers expressed as the ratio between unemployed plus participants in ALMPs over the total labour force. Estevao (2007) uses the share of working age population employed in the business sector (employment rate in the business sector). OECD (1993) uses the employment rate. Altavilla - Caroleo (2006) use alternatively unemployment rate, employment rate, and youth unemployment rate. Hujer-Zeiss (2003), instead, use the outflow from unemployment into regular employment relative to the labour force in order to internalise also displacement effects. Hagen (2003) uses the unemployment rate, the matching function approach as in Hujer - Zeiss (2003), and the ratio of regular employment to the labour force as three alternative dependent variables to be analysed.

12 Public expenditure is inclusive of EU subsidies aimed at fostering spending on particular policies such as the European Social Fund. EU transfers enter in the budget of the - national, regional or local - public administration as an income in the revenue side and as part of the expenditure in the particular projects co-financed by the EU. 
index, the trade union density variable, and the average tax wedge. The availability of institutional variables is very limited for the group of periphery countries. In addition, their time persistence makes their level of significance very poor when using annual data. For these reasons, the role of institutional variables is analysed in a robustness check, whose results are reported in the Appendix.

\section{ESTIMATIONS AND RESULTS}

\subsection{Econometric modelling}

We build and estimate a panel data model in which the employment rate is the dependent variable and the level of public expenditure on active labour market policies is among the set of explanatories:

Employment $_{\mathrm{it}}=\rho$ Employment $_{\mathrm{it}-1}+\beta_{1} \mathrm{ALMP}_{\mathrm{it}}+\beta_{2} \mathrm{PLMP}_{\mathrm{it}}+\gamma \mathrm{m}_{\mathrm{it}}+\mu_{\mathrm{i}}+\lambda_{\mathrm{t}}+\varepsilon_{\mathrm{it}}$

where Employment tit $_{\text {is }}$ the employment rate in country $i$ at time $t, A L M P$ and PLMP are the level of public expenditure as a share of GDP in active and passive labour market policies respectively. $m_{i t}$ is a vector of macroeconomic variables affecting the level of unemployment. It includes total factor productivity, terms of trade, the level of per capita production (in logarithmic form) and, in an extended version of the model, also the level of public expenditure as a share of GDP, labour productivity, and the level of public compensation of employees. An extension of the original model, reported in the Appendix, includes, in addition, a vector of institutional variables among the set of explanatories: the employment protection index, the trade union density variable and the average tax wedge; $\mu_{i}$ is the country specific term and $\lambda_{t}$ are the time-dummies. A specification of the model substitutes the time-dummies for a unit specific linear time-trend.

We estimated the coefficients using the one-step version of the system GMM estimator (Arellano - Bover 1995; Blundell - Bond 1998) instead of the two-step procedure. ${ }^{13}$ The use of this estimator captures two important features: firstly, it is able to capture the dynamic behaviour of the variables, as our dependent variable seems to be strongly time-persistent; and, secondly, the GMM estimate also

13 This is based on the findings of Judson - Owen (1996), applied to the length of the crosssection and time dimensions of our dataset. The system GMM estimator improves the efficiency of the "difference GMM" estimator (Arellano - Bond 1991) by introducing additional assumptions of no correlation between the fixed-effects and the first differences of the instrumenting variables. 
controls for the endogeneity of the control by using the lagged values of the levels of the endogenous and the predetermined variables as instruments. Some of our control variables and, in particular, the variable on which we focus our attention (ALMPs) could be endogenous, as the levels of employment could drive the share of the public budget devoted to active labour market policies. Ignoring this reverse causality issue might lead to the overestimation of the causal relationship in the other direction. ${ }^{14}$ It is necessary to test for the validity of the instruments as well as for the presence of serial correlation in the residuals once the equation has been estimated.

The model was estimated introducing the variables in first differences. This is motivated by the suspicion that most variables could be non-stationary, as revealed by preliminary estimations of the equation in levels and the examination of their residuals. The outcome of the Im et al. (2003) unit root test is also reported in the Appendix (Table A1). The tests ${ }^{15}$ reinforce the hypothesis that most variables might be I(1), except for loggdppc.

Alternatively, we might think that the omission of relevant dynamics in the model is the source of the complications observed in the estimation in levels. It seems reasonable to assume that employment in a given period may be correlated with past trends in other macroeconomic variables. Parameter estimates based on a static estimator are biased and inconsistent if the true model is not static. For that reason, we propose a panel data model that includes unobserved countryspecific effects and allow for the existence of lagged values of the explanatory variables, in addition to the lagged values of the dependent variable. We want to allow for the possibility that the variations of past control variables may still affect current variations in employment. The specification of this equation to be estimated from panel data can be expressed as an ARDL (autoregressive distributed lag) model:

$$
\begin{gathered}
\text { Employment }_{\mathrm{it}}=\sum \rho_{\mathrm{r}} \text { Employment }_{\mathrm{it}-\mathrm{r}}+\beta^{1} \mathrm{CONTROL}_{\mathrm{it}}+\beta^{2} \mathrm{CONTROL}_{\mathrm{it}-1}+ \\
+\mu_{\mathrm{i}}+\lambda_{\mathrm{t}}+\varepsilon_{\mathrm{it}}
\end{gathered}
$$

where CONTROL is a vector of variables including ALMP, PLMP, and the variables included in $m$. Long-term relationships between the variables may be easily derived from the estimation of this equation. Equation (2) is, again, estimated using the one-step Arellano - Bond (1991) GMM estimator, and in the presence

14 The estimations reported assume that the variables ALMP and PLMP could be endogenous, while the remaining variables are assumed to be predetermined.

15 Results, however, should be interpreted with caution in the light of the performance revealed by the Monte Carlo experiments for the panel dimensions under consideration (Im et al. 2003). 
of a common time trend or unit-specific time trends as alternatives to the time dummies $\lambda_{t}$.

The interpretation of the estimation of the ARDL model represented by equation (2) is not straightforward. Very often, the two coefficients attached to the same variable (in levels and one period lagged) differ substantially in terms of size and significance level. This makes it difficult to assess whether a variable has a significant impact on the dependent variable, as well as the size of the impact. For that reason, long-run coefficients are constructed from the outcome of estimating equation (2). Assuming an economy in its steady state, with a constant employment rate and a constant value of the explanatory variables over time, we can work out long-term coefficients:

$$
\beta^{\text {longterm }}=\left(\beta^{1}+\beta^{2}\right) /\left(1-\Sigma \rho_{\mathrm{r}} \text { Employment }_{\mathrm{it}-\mathrm{r}}\right) .
$$

Standard errors for coefficients obtained with this procedure may be easily computed using Stata. They are computed applying a delta method. A general discussion of this method can be found in Wooldridge (2002). $\beta^{\text {longterm }}$ represents, therefore, the difference between the level of the dependent variable in both steady states, before and after the unitary increase of the dependent variable.

\subsection{Results}

Tables 3 and 4 show the results obtained while running identical estimations, but after splitting the sample into two subsamples of similar size. ${ }^{16}$ Table 3 presents results for the 18 countries of the periphery, whose labour market performance is relatively worse, ${ }^{17}$ while Table 4 presents similar results for the 10 core countries $^{18}$.

The estimates assume four alternative models with respect to the control variables included. Firstly, we introduced only the variables that are common to most

16 The criterion used for the allocation of EU countries across core and periphery is precisely the relative distribution of the European Social Fund among countries in per capita terms, as the ESF is allocated according to indicators of labour market performance. The two groups created are similar in terms of GDP and population.

17 These are Bulgaria, Cyprus, Czech Republic, Estonia, Finland, Greece, Hungary, Italy, Ireland, Latvia, Lithuania, Malta, Poland, Portugal, Romania, Spain, Slovenia, and Slovakia, although some units are dropped for estimating longer versions of the model due to poor data availability.

18 Austria, Belgium, Denmark, France, Germany, Luxembourg, Netherlands, Norway, Sweden, and United Kingdom. 
Table 3. Determinants of employment rate in periphery countries. First differences

\begin{tabular}{|c|c|c|c|c|c|c|}
\hline & {$[1]$} & {$[2]$} & {$[3]$} & {$[4]$} & {$[5]$} & {$[6]$} \\
\hline \multirow[t]{2}{*}{ emprate $_{\mathrm{t}-1}$} & $0.46450 * * *$ & $0.4528 * * *$ & $0.4953 * * *$ & $0.4491 * * *$ & $0.4263 * * *$ & $0.4644 * * *$ \\
\hline & 0.032 & 0.032 & 0.035 & 0.032 & 0.041 & 0.034 \\
\hline \multirow[t]{2}{*}{ ALMP } & $1.7597 * * *$ & $2.0737 * * *$ & $1.7576^{* * *}$ & $1.9056^{* * *}$ & $1.5798 * * *$ & $1.6686^{* * *}$ \\
\hline & 0.570 & 0.592 & 0.589 & 0.600 & 0.593 & 0.611 \\
\hline \multirow[t]{2}{*}{ PLMP } & $-2.4125^{* * *}$ & $-2.8604 * * *$ & $-2.3600 * * *$ & $-2.5019 * * *$ & $-2.3166^{* * *}$ & $-2.4456 * * *$ \\
\hline & 0.195 & 0.191 & 0.222 & 0.202 & 0.228 & 0.208 \\
\hline \multirow[t]{2}{*}{$\mathrm{tfp}$} & $0.1917 * * *$ & & $0.1727 * * *$ & $0.1753^{* * *}$ & $0.1007 * * *$ & $0.1941 * * *$ \\
\hline & 0.020 & & 0.023 & 0.020 & 0.027 & 0.022 \\
\hline \multirow[t]{2}{*}{ labprod } & & $0.0818 * * *$ & & & & \\
\hline & & 0.018 & & & & \\
\hline \multirow[t]{2}{*}{ tot } & -0.0073 & -0.0135 & -0.0109 & & 0.026 & -0.0118 \\
\hline & 0.023 & 0.023 & 0.024 & & 0.025 & 0.024 \\
\hline \multirow[t]{2}{*}{ lodgdppc } & 0.1891 & 0.1022 & 0.1394 & & 0.1759 & 0.2693 \\
\hline & 0.114 & 0.116 & 0.112 & & 0.120 & 0.224 \\
\hline \multirow[t]{2}{*}{ pexp } & & & 0.0209 & & & \\
\hline & & & 0.025 & & & \\
\hline \multirow[t]{2}{*}{ compempl } & & & $-0.2845^{* *}$ & & & \\
\hline & & & 0.115 & & & \\
\hline $\begin{array}{l}\text { Sargan test } \\
\left(\mathrm{p} \text {-value) }{ }^{[1]}\right.\end{array}$ & $398.6(.25)$ & $441.8(.02)$ & $385.9(.54)$ & $356.5(.24)$ & $358.9(.44)$ & $355.8(.59)$ \\
\hline \multirow[t]{2}{*}{$\begin{array}{l}\text { Autocorr. Test } \\
\text { (p-value) }{ }^{[2]}\end{array}$} & $-3.02(.00)$ & $-3.02(.00)$ & $-3.09(.00)$ & $-3.11(.00)$ & $-3.25(.00)$ & $-2.99(.00)$ \\
\hline & $-0.66(.50)$ & $-1.41(.15)$ & $-0.68(.49)$ & $-0.88(.37)$ & $-0.54(.58)$ & $-0.65(.51)$ \\
\hline time dummies & no & no & no & no & yes & no \\
\hline $\begin{array}{l}\text { country- } \\
\text { specific time } \\
\text { trend }\end{array}$ & no & no & no & no & no & yes \\
\hline Obs. (groups) & $257(18)$ & $261(18)$ & $246(18)$ & $259(18)$ & $257(18)$ & $257(18))$ \\
\hline
\end{tabular}

Notes: $*, * * * *$ denote significance levels at the $10 \%, 5 \%$, and $1 \%$ level, respectively.

${ }^{[1]}$ Sargan test of overidentifying restrictions.

${ }^{[2]}$ Arellano and Bond (1991) test for autocorrelation (of order 1 and order 2) in the error term.

of the reviewed literature; secondly, labour productivity is introduced as an alternative to total factor productivity; thirdly, we considered also other macroeconomic variables that could drive employment rates such as public expenditure and compensation of employees; and, finally, we considered only variables that show clear statistical significance. Column 5 assumes, over the baseline model of column 1, the presence of time dummies, while column 6 introduces, instead, a country-specific linear time trend.

At this stage, it is relevant to mention two important points in order to interpret fiscal variables. The first point refers to the findings of several studies on 
Table 4. Determinants of employment rate in core countries. First differences

\begin{tabular}{|c|c|c|c|c|c|c|}
\hline & {$[1]$} & {$[2]$} & [3] & {$[4]$} & {$[5]$} & {$[6]$} \\
\hline \multirow[t]{2}{*}{ emprate $_{t-1}$} & $0.2725 * * *$ & $0.2345^{* * *}$ & $0.1892 * * *$ & $0.2764 * * *$ & $0.2361 * * *$ & $0.2467 * * *$ \\
\hline & 0.041 & 0.041 & 0.042 & 0.042 & 0.047 & 0.043 \\
\hline \multirow[t]{2}{*}{ ALMP } & -0.4265 & -0.3734 & -0.0839 & -0.4924 & $-.07204^{*}$ & -0.6113 \\
\hline & 0.368 & 0.362 & 0.375 & 0.375 & 0.422 & 0.385 \\
\hline \multirow[t]{2}{*}{ PLMP } & $-2.4639 * * *$ & $-2.6673 * * *$ & $-2.2693 * * *$ & $-2.4030 * * *$ & $-1.9746^{* * *}$ & -2.5622 \\
\hline & 0.244 & 0.225 & 0.250 & 0.249 & 0.312 & 0.255 \\
\hline \multirow[t]{2}{*}{$\mathrm{tfp}$} & 0.0185 & & -0.0564 & 0.0081 & 0.0327 & 0.0138 \\
\hline & 0.032 & & 0.038 & 0.031 & 0.050 & 0.033 \\
\hline \multirow[t]{2}{*}{ labprod } & & $-0.0553^{* *}$ & & & & \\
\hline & & 0.025 & & & & \\
\hline \multirow[t]{2}{*}{ tot } & 0.0065 & 0.0042 & $-0.0301 *$ & & 0.0054 & 0.0075 \\
\hline & 0.015 & 0.014 & 0.017 & & 0.014 & 0.015 \\
\hline \multirow[t]{2}{*}{ lodgdppc } & -0.1848 & $-0.2648 * *$ & $-0.2637 * *$ & & -0.1814 & -0.2798 \\
\hline & 0.134 & 0.132 & 0.128 & & 0.272 & 0.526 \\
\hline \multirow[t]{2}{*}{ pexp } & & & $-0.0589 *$ & & & \\
\hline & & & 0.033 & & & \\
\hline \multirow[t]{2}{*}{ compempl } & & & -0.1344 & & & \\
\hline & & & 0.176 & & & \\
\hline $\begin{array}{l}\text { Sargan test } \\
\text { (p-value) }{ }^{[1]}\end{array}$ & $344.6(.67)$ & $349.0(.57)$ & $403.9(.22)$ & $311.2(436)$ & $316.3(.72)$ & $316.9(.87)$ \\
\hline \multirow[t]{2}{*}{$\begin{array}{l}\text { Autocorr. Test } \\
\text { (p-value) }\end{array}$} & $-2.79(.00)$ & $-2.78(.00)$ & $-2.74(.00)$ & $-2.77(.00)$ & $-2.82(.00)$ & $-2.79(.00)$ \\
\hline & $-0.44(.65)$ & $-0.38(.70)$ & $-0.47(.63)$ & $-0.40(.68)$ & $-0.13(.89)$ & $-0.50(.61)$ \\
\hline time dummies & no & no & no & no & yes & no \\
\hline $\begin{array}{l}\text { country-specific } \\
\text { time trend }\end{array}$ & no & no & no & no & no & yes \\
\hline Obs. (groups) & $227(10)$ & $225(10)$ & $216(10)$ & $227(10)$ & $227(10)$ & $227(10)$ \\
\hline
\end{tabular}

Notes: $*, * *, * * *$ denote significance levels at the $10 \%, 5 \%$, and $1 \%$ level, respectively.

${ }^{[1]}$ Sargan test of overidentifying restrictions.

${ }^{[2]}$ Arellano and Bond (1991) test for autocorrelation (of order 1 and order 2) in the error term.

the growth effect of fiscal variables (Kneller et al. 1999), which showed that the interpretation of the coefficients associated to fiscal variables must take into account the implicit budgetary assumptions. In our estimation, for example, the coefficient associated to the variable public expenditure estimates the impact on employment of an increase in public expenditure financed by the omitted fiscal variables (tax revenues or budgetary deficit).

The second point, also in line with the growth literature, ${ }^{19}$ refers to the fact that the final impact of an increase of a fiscal variable depends on its current level.

19 See, for example, Afonso et al. (2011). 
Increasing a type of public expenditure may have a positive impact on economic growth or employment up to a certain level, at which probably additional increases seem to have an insignificant impact. If the level of public expenditure in that category increased far above this threshold, its relationship with employment and growth might become negative. Therefore, when we estimate an insignificant coefficient associated to a fiscal variable, this could reflect the fact that the level of this variable is currently near its optimum.

The comparison of both tables yields an interesting result: while public expenditure on ALMPs seems to be a significant determinant of employment rate in the periphery, its significance gets weaker for the core countries. ${ }^{20}$ That might reflect the fact that the level of public expenditure on ALMPs is below its optimum level in the periphery, which justifies additional policy measures such as continuing ESF transfers to foster larger ALMPs expenditure. As for the core countries, their larger level of ALMPs expenditure seems to yield no additional benefit on employment, at least compared to other types of public expenditure. In terms of size, we can notice that the coefficient attached to ALMPs is similar, slightly lower, compared to the coefficients estimated in Estevao (2007) and slightly higher to those in Estevao (2003). In both cases, the estimations cover a sub-set of OECD countries.

Regarding other explanatory variables, the increase in the employment rate is still strongly time persistent, as it seems to be driven by its own value in the previous period with a coefficient around 0.3. The coefficient estimated for PLMPs suggests that a one percent increase (over GDP) of public expenditure in passive labour market policies could induce a 2 percentage point decrease in the employment rate. The size of the coefficients for PLML is also similar to the ones estimated in Estevao $(2003,2007)$, although the variability of the coefficient to the alternative specifications is smaller in our case.

While total factor productivity improvements seem to foster the employment rate in peripheral countries, the impact of labour productivity growth on the employment rate seems less obvious. Both results, although contradictory, are also intuitive. ${ }^{21}$ Larger multifactor productivity foments more activity and, therefore, demands further labour supply while, simultaneously, higher labour productivity diminishes the amount of labour necessary to sustain the level of production. The contribution of the other control variables is more controversial, as the level of significance of the coefficients estimated are quite poor. Finally, the contribution

\footnotetext{
20 A similar result is found in Furceri - Zdzienicka (2012), who estimate the impact of ALMPs on GDP growth in a set of OECD countries, finding no significant effects, in contrast to other categories of social spending.

${ }^{21}$ In line with the literature, see Basanini (2008).
} 
Table 5. Determinants of employment rate in periphery countries. Long-term coefficients

\begin{tabular}{|c|c|c|c|c|c|c|}
\hline & [1] & [2] & [3] & [4] & [5] & [6] \\
\hline \multirow[t]{2}{*}{ ALMP } & $24.206 * * *$ & $24.433 * * *$ & $19.678 * * *$ & $29.480 * * *$ & $25.916 * * *$ & $25.941 * * *$ \\
\hline & 6.377 & 5.852 & 6.883 & 7.312 & 6.191 & 7.965 \\
\hline \multirow[t]{2}{*}{ PLMP } & $-7.9924 * * *$ & $-8.4417 * * *$ & $-5.0672 * *$ & $-9.0526 * * *$ & $-8.1432 * * *$ & $-9.3131 * * *$ \\
\hline & 1.628 & 1.540 & 2.050 & 2.212 & 1.642 & 1.916 \\
\hline \multirow[t]{2}{*}{$\mathrm{tfp}$} & $0.2798 * *$ & & $0.2644 * *$ & $0.4090 * * *$ & $0.3630 * *$ & $0.3786^{*}$ \\
\hline & 0.114 & & 0.124 & 0.127 & 0.149 & 0.196 \\
\hline \multirow[t]{2}{*}{ labprod } & & 0.0782 & & & & \\
\hline & & 0.061 & & & & \\
\hline \multirow[t]{2}{*}{ tot } & 0.0337 & -0.0311 & 0.1855 & & 0.1971 & 0.0971 \\
\hline & 0.144 & 0.130 & 0.179 & & 0.142 & 0.197 \\
\hline \multirow[t]{2}{*}{ lodgdppc } & 3.2447 & $4.2897 * *$ & 3.0647 & & $3.9373 * *$ & 0.8235 \\
\hline & 2.001 & 1.829 & 2.110 & & 1.916 & 3.608 \\
\hline \multirow[t]{2}{*}{ pexp } & & & $-0.8491 * * *$ & & & \\
\hline & & & 0.243 & & & \\
\hline \multirow[t]{2}{*}{ compempl } & & & 0.8207 & & & \\
\hline & & & 0.644 & & & \\
\hline $\begin{array}{l}\text { Sargan test } \\
(p-\text { value })^{[1]}\end{array}$ & $403.6(.08)$ & $442.8(.00)$ & $388.2(.28)$ & $356.1(.10)$ & $358.1(.26)$ & $359.1(.32)$ \\
\hline \multirow[t]{2}{*}{$\begin{array}{l}\text { Autocorr. Test } \\
\text { (p-value) }{ }^{[2]}\end{array}$} & $-3.15(.00)$ & $-3.34(.00)$ & $-3.27(.00)$ & $-2.96(.00)$ & $-3.27(.00)$ & $-3.06(.00)$ \\
\hline & $-1.12(.25)$ & $-1.53(.12)$ & $-1.27(.20)$ & $-0.72(.46)$ & $-0.90(.36)$ & $-1.16(.24)$ \\
\hline time dummies & no & no & no & no & yes & no \\
\hline $\begin{array}{l}\text { country-specific } \\
\text { time trend }\end{array}$ & no & no & no & no & no & yes \\
\hline Obs. (groups) & $252(18)$ & $256(18)$ & $241(18)$ & $253(18)$ & $252(18)$ & $252(18)$ \\
\hline
\end{tabular}

Notes: $* * *, * * *$ denote significance levels at the $10 \%, 5 \%$, and $1 \%$ level, respectively.

${ }^{[1]}$ Sargan test of overidentifying restrictions.

${ }^{[2]}$ Arellano and Bond (1991) test for autocorrelation (of order 1 and order 2) in the error term.

of the time dummies or the country-specific time trends to improve the estimation seems marginal according to the estimates shown in these tables.

Regarding the institutional variables, although many other studies have underlined their contribution to the level of equilibrium employment ${ }^{22}$ in the labour market, their impact may be partially absorbed by the unit-specific term in this estimation, as they are highly time persistent (at least according to the time frequency considered in this paper). For that reason, institutional variables have been removed from the original model, although a robustness check - reported in

22 See, for example, Nunziata (2002). 
Table 6. Determinants of employment rate in core countries. Long-term coefficients

\begin{tabular}{|c|c|c|c|c|c|c|}
\hline & [1] & [2] & [3] & [4] & [5] & [6] \\
\hline \multirow[t]{2}{*}{ ALMP } & 0.3093 & 0.1207 & 1.421 & -3.7089 & 0.2366 & 0.7275 \\
\hline & 3.234 & 3.012 & 3.949 & 4.061 & 2.577 & 2.860 \\
\hline \multirow[t]{2}{*}{ PLMP } & -1.3406 & -1.2118 & 1.1278 & $-3.5392 *$ & 0.9296 & -1.4546 \\
\hline & 1.678 & 1.529 & 1.725 & 1.841 & 1.380 & 1.429 \\
\hline \multirow[t]{2}{*}{ tfp } & 0.1984 & & 0.1121 & -0.0186 & -0.3053 & -0.0773 \\
\hline & 0.228 & & 0.231 & 0.149 & 0.250 & 0.292 \\
\hline \multirow[t]{2}{*}{ labprod } & & 0.2767 & & & & \\
\hline & & 0.176 & & & & \\
\hline \multirow[t]{2}{*}{ tot } & -0.1665 & $-0.1984 *$ & $-.3300 * *$ & & -0.1352 & $-0.1574 *$ \\
\hline & 0.115 & 0.105 & 0.138 & & 0.086 & 0.091 \\
\hline \multirow[t]{2}{*}{ lodgdppc } & -3.0783 & -8.7886 & -1.528 & & -1.1307 & 0.6895 \\
\hline & 5.527 & 6.265 & 5.237 & & 4.747 & 12.660 \\
\hline \multirow[t]{2}{*}{ pexp } & & & -0.444 & & & \\
\hline & & & 0.358 & & & \\
\hline \multirow[t]{2}{*}{ compempl } & & & -0.1789 & & & \\
\hline & & & 0.746 & & & \\
\hline $\begin{array}{l}\text { Sargan test } \\
(p-\text { value })^{[1]}\end{array}$ & $343.8(.55)$ & $355.3(.64)$ & $384.6(.32)$ & $266.9(.92)$ & $303.5(.78)$ & $322.8(.71)$ \\
\hline \multirow[t]{2}{*}{$\begin{array}{l}\text { Autocorr. test } \\
\text { (p-value) }{ }^{[2]}\end{array}$} & $-2.71(.00)$ & $-2.82(.00)$ & $-2.58(.00)$ & $-2.80(.00)$ & $-2.76(.00)$ & $-2.67(.00)$ \\
\hline & $-0.18(.84)$ & $-0.12(.90)$ & $-0.26(.79)$ & $-0.26(.79)$ & $-0.24(.80)$ & $-0.15(.87)$ \\
\hline time dummies & no & no & no & no & yes & no \\
\hline $\begin{array}{l}\text { country-specific } \\
\text { time trend }\end{array}$ & no & no & no & no & no & yes \\
\hline Obs. (groups) & $225(10)$ & $223(10)$ & $214(10)$ & $225(10)$ & $225(10)$ & $225(10)$ \\
\hline
\end{tabular}

Notes: $*, * * * * *$ denote significance levels at the $10 \%, 5 \%$, and $1 \%$ level, respectively.

${ }^{[1]}$ Sargan test of overidentifying restrictions.

${ }^{[2]}$ Arellano and Bond (1991) test for autocorrelation (of order 1 and order 2) in the error term.

the Appendix (Table A2) - reveals that the inclusion of institutional variables does not significantly alter the results reported here.

Tables 5 and 6 show the long-term coefficients estimated through equation (3), from the coefficients obtained in the estimation of equation (2) using the same GMM estimator (Arellano - Bover 1995) and including the variables in levels. Therefore, the absolute values of the coefficients ${ }^{23}$ are not comparable with those in Tables 3 and 4, which are obtained with variables in first-differences. However, regarding the sign and significance levels of the estimated coefficients,

23 The size of the coefficients may seem large, but we have to keep in mind that ALMPs (and also PLMPs) expenditure represent less than $1 \%$ of GDP in most countries. 
the results are not contradictory to those obtained from equation (1). In fact, the distance between the coefficients associated to ALMPs and other fiscal variables becomes more evident. The coefficient associated to the variable ALMP is positively significant only for periphery countries. As for the other control variables, we observe poorer levels of significance in general.

Our results do reinforce the hypothesis that ALMPs expenditure is more effective in the countries of the periphery, in which the current level of expenditure is actually lower. At this stage, it is necessary to assess to what extent this is a new finding. There are many studies ${ }^{24}$ revealing the positive relationship of ALMPs to employment growth. With a few exceptions, however, these rarely ${ }^{25}$ compare performance across groups of countries. Elkmesov et al. (1998), for example, introduce an interaction term in a robustness check that captures the relationship of unemployment benefits with a dummy representing three alternative groups of countries according to their level of ALMPs expenditure (low, intermediate, or high), within their sample of 20 OECD countries (1983-1994). Their results reveal a better performance of unemployment benefits (PLMPs) for the group of intermediate ALMPs spending and the worst performance for the group of countries with a low level of ALMPs expenditure. ${ }^{26}$ Estevao (2007) uses a sample of 16 OECD countries and he also estimates a larger coefficient for the subsample that excludes the Nordic countries, which are precisely those with a larger level of public expenditure on ALMPs. In both cases, the results presented in this paper are consistent with those in other studies, although not fully comparable.

\section{CONCLUSIONS}

The EU is searching for economic recipes that accelerate the exit from the prolonged recession and minimise the short-term impact on unemployment, which is already far above the socially acceptable level. One of the strategies has been the provision of an additional fiscal stimulus to Active Labour Market Policies (ALMPs), distributed through the ESF, in order to tackle the high level of youth

24 Some results have been already introduced in Section 3. A review of previous results with country-level data can be found in Calmfors et al. (2002)

25 Other studies investigating the impact of EU transfers on employment - mostly at the regional level - discriminate across units according to their eligibility to access the Funds (see Becker et al. 2010; Mohl - Hagen 2011). Their results, although more optimistic when related to the performance of economic growth, do reveal a poor impact of EU transfers on employment growth.

26 Bearing in mind that they use an interaction term and, therefore, their results are not wholly comparable with the ones reported in this paper. 
unemployment. At this point, research in the social sciences must be able to assess the impact of these policies in order to provide policy-makers with information for designing the necessary reforms.

Our paper tried to asses to what extent ALMPs were successful in 28 European countries. We first analysed the evolution and rules governing the distribution of the ESF since its creation as a qualitative assignment of its capacity to foster ALMPs expenditure in Member States. We also included a review of previous empirical analyses that demonstrate the positive link between ALMPs expenditure and employment growth in developed countries.

In order to fit these results to current methodological techniques and to distinguish between EU countries with heterogeneous performance in their labour markets, we built and estimated a panel data model that captures the impact of public expenditure on ALMPs, apart from other fiscal and macroeconomic variables, on the employment rate. The model is estimated by GMM, assuming the possible presence of the endogeneity of the explanatory variables and the non-stationary behaviour of the variables. The sample was split in order to estimate separately the coefficients in core and periphery countries, as the latter experience a significantly worse performance of the labour market. Finally, an alternative model assumed the stationarity of the variables, but a highly dynamic - autoregressive distributed lag - model.

Two main results were obtained from the quantitative analysis: firstly, the impact of increasing ALMPs public expenditure on employment may be larger than the impact of public expenditure as a whole, although the current level of ALMPs seems to be near its optimum threshold; and secondly, public expenditure on ALMPs seems to be significantly more beneficial in those countries in which the ESF is largely present. Thus, the results seem to confirm the recent political strategy focused on increasing the size of ESF transfers to Member States that suffer from higher unemployment rates.

\section{REFERENCES}

Afonso, A. - González-Alegre, J. (2011): Economic Growth and Budgetary Components: A Panel Assessment for the EU. Empirical Economics, 41(3): 703-723.

Altavilla, C. - Caroleo, F. E. (2006): Evaluating the Dynamic Effects of Active Labour Policies in Italy. Labour, 20(2): 349-382.

Arellano, M. - Bond, S. (1991): Some Tests of Specification for Panel Data: Monte Carlo Evidence and an Application to Employment Equations. Review of Economic Studies, 58(2): 227-297.

Arellano, M. - Bover, O. (1995): Another Look at the Instrumental Variables Estimation of ErrorComponent Models. Journal of Econometrics, 68(1): 29-51. 
Baccaro, L. - Rei, D. (2005): Institutional Determinants of Unemployment in OECD Countries: A Times-Series Cross-Section Analysis (1960-1998). International Institute for Labor Studies, Discussion Paper, No. 160, Geneva.

Bache, I. - George, S. - Bulmer, S. (2011): Politics in the European Union. Oxford: Oxford University Press.

Basanini, A. (2008): The Impact of Labour Market Policies on Productivity in OECD Countries. International Productivity Monitor, 17: 3- 15.

Basanini, A. - Duval, R. (2009): Unemployment Institutions, and Reform Complementarities: ReAssessing the Aggregate Evidence for OECD Countries. Oxford Review of Economic Policy, 25(1): 40-59.

Becker, S. O. - Egger, P. H. - Von Ehrlich, M. (2010): Going NUTS: The Effect of EU Structural Funds on Regional Performance. Journal of Public Economics, 94(9): 578-590.

Blanchard, O. - Wolfers, J. (2000): The Role of Shocks and Institutions in the Rise of European Unemployment: The Aggregate Evidence. Economic Journal, 110(462): 1-33.

Blundell, R. - Bond, S. (1998): Initial Conditions and Moment Restrictions in Dynamic Panel Data Models. Journal of Econometrics, 87(1): 115-143.

Boone, J. - Van Ours, J. C. (2009): Bringing Unemployment Back to Work: Effective Active Labour Market Policies. De Economist, 157(3): 293-313.

Calmfors, L. - Forslund, A. - Hemström, M. (2002): Does Active Labour Market Policies Work? Lessons from the Swedish Experiences. Institute for Labour Market Policy Evaluation Working Paper, No. 2002/4.

Chapple, S. (1999): Displacement Effects of Active Labour Market Policy. Report for the Department of Labour. Wellington: NZ Institute of Economic Research.

Elmeskov, J. - Martin, J. P. - Scarpetta, S. (1998): Key Lessons for Labour Market Reforms: Evidence from OECD Countries' Experiences. Swedish Economic Policy Review, 5(2): 205-252.

Estevao, M. (2003): Do Active Labor Market Policies Increase Employment? IMF Working Paper Series, No. WP/03/234.

Estevao, M. (2007): Labor Policies to Raise Employment. IMF Staff Papers, 54(1): 113-138.

European Commission (2007a): European Social Fund: 50 Years Investing In People. Luxembourg: Office for Official Publications of the European Communities.

European Commission (2007b): Cohesion Policy 2007-13. Commentaries and Official Texts. Luxembourg: Office for Official Publications of the European Communities.

European Commission (2007c): 18th Annual Report On The Implementation of the Structural Funds 2006. Commission Staff Working Document, No. COM(2007) 676 Final.

European Commission (2010): The European Social Fund: Active Labour Market Policies and Public Employment Services. Background Report. Brussels.

European Commission (2013): Promoting Jobs, Inclusion and Social Policy as an Investment. Luxemburg: Office for Official Publications of the European Communities.

European Communities (1998): The European Social Fund. An Overview of the Programming Period 1994-1999. Luxembourg: Office for Official Publications of the European Communities.

European Communities (2009): EU Budget 2008. Financial Report. Luxembourg: Office for Official Publications of the European Communities.

Flaig, G. - Rottmann, H. (2013): Labour Market Institutions and Unemployment: An International Panel Data Analysis. Empirica, 40:635-654.

Forslund, A. - Krueger, A. (1997): An Evaluation of the Swedish Active Labor Market Policy: News and Received Wisdom. In: The Welfare State in Transition: Reforming the Swedish Model. Cambridge: National Bureau of Economic Research. 
Furceri, D. - Zdzienicka, A. (2012): The Effects of Social Spending on Economic Activity: Empirical Evidence from a Panel of OECD Countries. Fiscal Studies, 33(1):129-152.

Hagen, T. (2003): Three Approaches to the Evaluation of Active Labour Market Policy in East Germany Using Regional Data. Centre for European Economic Research - ZEW, Discussion Paper, No. 03-27.

Hujer, R. - Caliendo, M. (2000): Evaluation of Active Labour Market Policy: Methodological Concepts and Empirical Estimates. Institute for the Study of Labour - IZA, Discussion Paper, No. 236.

Hujer, R. - Zeiss, C. (2003): Macroeconomic Impacts of ALMP on the Matching Process in West Germany. IZA Discussion Paper, No. 915.

Hujer, R. - Caliendo, M. - Zeiss, C. (2004): Macroeconomic Evaluation of Active Labour Market Policy. A Case Study for Germany. In: Descy, P. - Tessaring, M. (eds): Impact of Education and Training. Third Report on Vocational Training Research in Europe. Luxembourg: Office for Official Publications of the European Communities.

Im, K. S. - Pesaran, M. H. - Shin, Y. (2003): Testing for Unit Roots in Heterogenous Panels. Journal of Econometrics, 115(1): 53-74.

Jackman, R. - Pissarides, C. - Savouri, S. (1990): Labour Market Policies and Unemployment in the OECD. LSE - Centre for Economic Performance, Discussion Paper, No. 11.

Judson, R. A. - Owen, A. L. (1996): Estimating Dynamic Panel Data Models: A Practical Guide for Macroeconomists. Federal Reserve Board of Governors. Mimeo.

Kneller, R. - Bleaney, M. F. - Gemmell, N. (1999): Fiscal Policy and Growth: Evidence from OECD Countries. Journal of Public Economics, 74(2): 171-190.

Layard, R. - Nickell, S. - Jackman, R. (1991): Unemployment: Macroeconomic Performance and the Labour-Market. Oxford: Oxford University Press.

Mohl, P. - Hagen, T. (2011): Do EU Structural Funds Promote Regional Employment? Evidence from Dynamic Panel Data Models. ECB, Working Papers, No 1403.

Nickell, S. - Layard, R. (1999): Labor Market Institutions and Economic Performance. In: Handbook of Labor Economics, 3(C), pp. 3029-3084.

Nickell, S. - Nunziata, L. - Ochel, W. (2005): Unemployment in the OECD since the 1960s. What Do We Know? The Economic Journal, 115(1): 1-27.

Nunziata, L. (2002): Unemployment, Labour Market Institutions and Shocks. Nuffield College, University of Oxford, Economics Papers, No. 2002-W16.

OECD (1993): Economic Outlook. July, Paris.

Sachs, A. (2012): What Really Drives Unemployment? A Bayesian Approach to Determine the Impact of Institutions on the Unemployment Rate. Economic Bulletin, 32(1): 1008-1019.

Scarpetta, S. (1996): Assessing the Role of Labour Market Policies and Institutional Settings of Unemployment: A Cross-Country Study. OECD Economic Studies, 26: 43-98.

Váradi, B. (2013): How can We Measure the Quality of Labour Market Related Decision-Making and Policy Design in Central- and Eastern European EU Member States and What Are Its Structural Determinants? GRINCOH Working Papers, WP4.5.2.

Vis, B. (2012): Under which Conditions does Spending on Active Labor Market Policies Increase? An Fsqca Analysis of 53 Governments between 1985 and 2003. European Political Science Review, 3(2): 229-252.

Wooldridge, J. M. (2002): Econometric Analysis of Cross Section and Panel Data. Cambridge, MA: MIT Press.

Zetterberg, J. (1995): Unemployment, Labour Market Policy and the Wage Bargaining System. Fackföreningsrörelsens Institut för ekonomisk forskning - FIEF Reprint Series, 99: 57-115. 


\section{APPENDIX}

Table A1. Panel unit root test

\begin{tabular}{lcccccc}
\hline & \multicolumn{3}{c}{ Levels } & \multicolumn{3}{c}{ First-Differences } \\
\cline { 2 - 7 } & core & Periphery & Full sample & core & Periphery & Full sample \\
\hline emprate & 0.655 & -0.247 & 0.594 & -8.360 & -3.603 & -7.317 \\
$P$-value & 0.74 & 0.40 & 0.72 & 0.00 & 0.00 & 0.00 \\
ALMP & 0.578 & 1.372 & 2.181 & -12.616 & -8.260 & -13.528 \\
$P$-value & 0.72 & 0.91 & 0.99 & 0.00 & 0.00 & 0.00 \\
PLMP & -0.788 & 1.379 & 1.770 & -5.609 & -4.666 & -8.013 \\
$P$-value & 0.22 & 0.92 & 0.96 & 0.00 & 0.00 & 0.00 \\
tfp & 3.252 & 1.091 & 2.160 & -8.103 & -8.399 & -10.678 \\
$P$-value & 1.00 & 0.86 & 0.98 & 0.00 & 0.00 & 0.00 \\
labprod & 0.883 & 4.521 & 6.731 & -9.627 & -8.917 & -12.872 \\
$P$-value & 0.81 & 1.00 & 1.00 & 0.00 & 0.00 & 0.00 \\
tot & 0.566 & -2.721 & -3.407 & -21.524 & -25.344 & -33.868 \\
$P$-value & 0.71 & 0.00 & 0.00 & 0.00 & 0.00 & 0.00 \\
lodgdppc & 1.705 & -5.179 & -5.411 & & & \\
$P$-value & 0.96 & 0.00 & 0.00 & & & \\
pexp & -1.258 & -4.065 & -4.039 & -16.357 & -17.286 & -23.598 \\
$P$-value & 0.10 & 0.00 & 0.00 & 0.00 & 0.00 & 0.00 \\
compempl & -0.798 & -2.649 & -2.882 & -24.765 & -13.654 & -24.183 \\
$P$-value & 0.21 & 0.00 & 0.00 & 0.00 & 0.00 & 0.00 \\
\hline
\end{tabular}

Notes: Im-Pesaran-Shin unit root test. The null hypothesis that all the panels contain a unit root (although the parameter is not assumed to be identical across panels) is tested against the alternative that the fraction of panels that are stationary is nonzero. Cross-sectional averages are subtracted from the series in order to mitigate the impact of cross-sectional dependence. 
Table A2. Determinants of employment rate. Institutional variables

\begin{tabular}{|c|c|c|c|c|c|c|}
\hline & {$[1]$} & $\begin{array}{l}{[2]} \\
\text { periphery }\end{array}$ & {$[3]$} & {$[4]$} & $\begin{array}{l}{[5]} \\
\text { core }\end{array}$ & {$[6]$} \\
\hline \multirow{2}{*}{ emprate $_{\mathrm{t}-1}$} & $0.3971 * * *$ & $0.3998 * * *$ & $0.3641 * * *$ & $0.2060 * * *$ & $0.1530 * *$ & $0.1238 * *$ \\
\hline & 0.050 & 0.063 & 0.058 & 0.057 & 0.064 & 0.061 \\
\hline \multirow[t]{2}{*}{ ALMP } & $1.9872 * *$ & $1.7753 * *$ & $1.9241 * *$ & -0.6361 & -0.8466 & -0.7171 \\
\hline & 0.770 & 0.792 & 0.806 & 0.485 & 0.531 & 0.482 \\
\hline \multirow[t]{2}{*}{ PLMP } & $-2.5596 * * *$ & $-2.3050 * * *$ & $-2.5990 * * *$ & $-2.4990 * * *$ & $-2.1381 * * *$ & $-2.5178 * * *$ \\
\hline & 0.276 & 0.315 & 0.294 & 0.330 & 0.410 & 0.333 \\
\hline \multirow[t]{2}{*}{$\mathrm{tfp}$} & $0.1741 * * *$ & $0.1251 * * *$ & $0.1642 * * *$ & 0.0112 & 0.0581 & 0.0125 \\
\hline & 0.037 & 0.042 & 0.039 & 0.043 & 0.064 & 0.044 \\
\hline \multirow[t]{2}{*}{ tot } & -0.0139 & 0.0389 & -0.0288 & 0.0020 & 0.0006 & -0.0071 \\
\hline & 0.037 & 0.042 & 0.039 & 0.020 & 0.020 & 0.020 \\
\hline \multirow[t]{2}{*}{ lodgdppc } & -0.1144 & 0.1458 & 0.5731 & -0.0413 & 0.3082 & 1.4264 \\
\hline & 0.384 & 0.672 & 1.043 & 0.324 & 0.794 & 1.015 \\
\hline \multirow[t]{2}{*}{ emprotection } & -0.1382 & 0.0853 & -0.1365 & 0.1353 & 0.2141 & -0.0050 \\
\hline & 0.236 & 0.256 & 0.444 & 0.219 & 0.252 & 0.344 \\
\hline \multirow[t]{2}{*}{ tradeundens } & -0.0235 & 0.0078 & -0.0204 & -0.0131 & -0.0150 & $-0.0932 * *$ \\
\hline & 0.027 & 0.029 & 0.038 & 0.022 & 0.025 & 0.042 \\
\hline \multirow[t]{2}{*}{ taxwedge } & -0.0277 & -0.0173 & 0.0029 & $0.0570 * *$ & $0.0432 *$ & 0.0495 \\
\hline & 0.027 & 0.026 & 0.058 & 0.024 & 0.024 & 0.041 \\
\hline $\begin{array}{l}\text { Sargan test } \\
\text { (p-value) }{ }^{[1]}\end{array}$ & $174.5(.78)$ & $158.6(.62)$ & $161.2(.82)$ & $209.7(.43)$ & $198.3(.19)$ & $204.3(.34)$ \\
\hline \multirow[t]{2}{*}{$\begin{array}{l}\text { Autocorr. Test } \\
\text { (p-value) }{ }^{[2]}\end{array}$} & $-267(.00)$ & $-2.96(.00)$ & $-2.66(.00)$ & $-2.84(.00)$ & $-2.79(.00)$ & $-2.78(.00)$ \\
\hline & $-1.01(.30)$ & $-0.26(.79)$ & $-1.08(.27)$ & $-0.53(.59)$ & $-0.30(.76)$ & $-0.75(.45)$ \\
\hline time dummies & no & yes & no & no & yes & no \\
\hline $\begin{array}{l}\text { country-specific } \\
\text { time trend }\end{array}$ & no & no & yes & no & no & yes \\
\hline Obs. (groups) & 199(11) & 199(11) & 199(11) & $216(10)$ & $216(10)$ & $216(10)$ \\
\hline
\end{tabular}

